\title{
Pemanfaatan Limbah Produksi Tape Singkong Sebagai Sumber Energi Alternatif Biogas Dan Biobriket Untuk Industri Rumah Tangga
}

\author{
Audiananti Meganandi Kartini, Firda Lutfiatul Fitria, Muammar Kadhafi \\ Fakultas Teknik, Universitas Jember \\ audiamega@unej.ac.id
}

\begin{abstract}
Abstrak
Bondowoso memiliki industri pengolahan tape, salah satunya adalah home industri tape singkong "Seger Wareg" Maesan Bondowoso. Selain memberi keuntungan secara ekonomi, kegiatan produksi juga menimbulkan masalah berupa limbah kulit singkong. Produksi 200$300 \mathrm{~kg}$ tape dapat menghasilkan sekitar 40-60 kg limbah kulit singkong. Kulit singkong dianggap limbah yang tidak berguna oleh sebagian industri tape singkong. Oleh karena itu, bahan ini masih belum banyak dimanfaatkan dan dibuang begitu saja dan umumnya hanya digunakan sebagai pakan ternak, sedangkan kulit singkong dinilai kurang baik sebagai pakan ternak karena mengandung sianida. Kulit singkong memiliki kandungan HCN yang sangat tinggi yaitu sebesar 18,0 - 309,4 ppm untuk per 100 gram kulit singkong (Nur Richana, 2013). $\mathrm{HCN}$ atau asam sianida merupakan zat yang bersifat racun baik dalam bentuk bebas maupun kimia, yaitu glikosida, sianogen phaseulonathin, linamarin dan metillinamarin/lotaustrain (Coursey, 1973). Penyelesaian masalah ini dilakukan dalam skema pengabdian kepada masyarakat melalui tahapan memberi sosialisasi tentang pengelolaan sampah, pengolahan limbah dan dampaknya pada lingkungan serta menginisiasi dan memberikan bantuan kepada masyarakat contoh rekator biogas skala rumah tangga yang nantinya dapat diperbanyak sesuai kebutuhan serta memberikan pengetahuan tentang pembuatan biobriket dari limbah kulit singkong. Pelaksanaan kegiatan pengabdian kepada masyarakat ini antara lain; (a) pemaparan materi pengelolaan limbah kulit singkong, (b) pembagian reaktor biogas dan briket, (c) praktek pembuatan reaktor dan (d) uji nyala api terhadap biogas yang telah terbentuk.
\end{abstract}

Kata Kunci: Singkong, Tape, Biogas, Biobriket

\section{PENDAHULUAN}

\subsection{Analisa Situasi}

Tape merupakan salah satu makanan olahan yang terbuat dari ubi kayu atau singkong yang difermentasi. Makanan ini sangat popular di seluruh daerah diIndonesia, namun tape singkong sangat terkenal sebagai makanan khas Kabupaten Bondowoso. Agroindustri tape di Kabupaten Bondowoso telah ada sejak tahun 1960 dan merupakan industri turun-menurun (Octaviani et al, 2014). Hampir semua kecamatan di Bondowoso memiliki industri pengolahan tape, salah satunya adalah Kecamatan Maesan yang dikenal memiliki produksi singkong yang berkualitas baik. Di daerah tersebut terdapat sentra industri tape singkong yang dapat menghasilkan beberapa kwintal tape setiap harinya untuk didistribusikan ke beberapa wilayah di Jawa Timur seperti Kabupaten Situbondo, Kabupaten Jember, Kabupaten Banyuwangi dan Kabupaten Madiun. Salah satunya adalah home industri tape singkong "Seger Wareg" Maesan Bondowoso. 


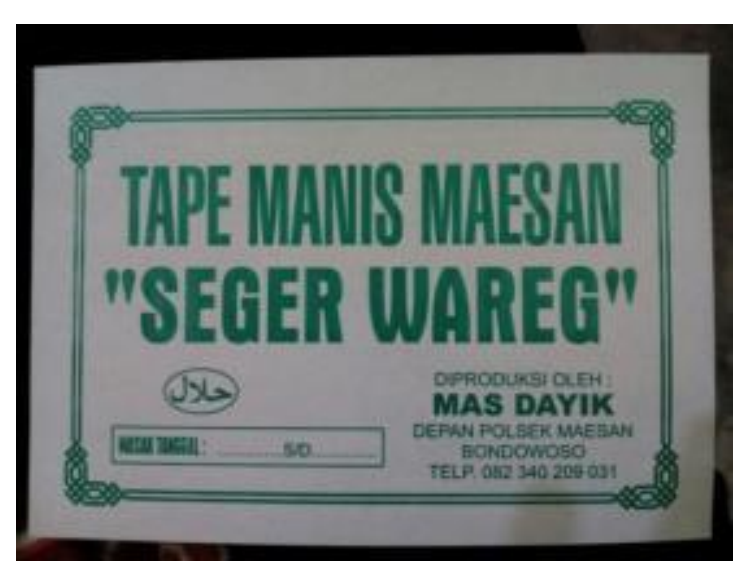

Gambar 1.1 Tape produksi home industri tape singkong "Seger Wareg” Maesan Bondowoso

Produksi tape ketela pohon di sentra industri tape dengan produksi sekitar 200-300 kg tape dapat menghasilkan sekitar 40-60 kg limbah kulit singkong, dengan asumsi berat kulit singkong 0,2 kg per kg umbi singkong. Kulit singkong sering kali dianggap limbah yang tidak berguna oleh sebagian industri tape singkong. Oleh karena itu, bahan ini masih belum banyak dimanfaatkan dan dibuang begitu saja dan umumnya hanya digunakan sebagai pakan ternak, sedangkan kulit singkong dinilai kurang baik sebagai pakan ternak karena mengandung sianida. Kulit singkong memiliki kandungan HCN yang sangat tinggi yaitu sebesar 18,0 - 309,4 ppm untuk per 100 gram kulit singkong (Nur Richana, 2013). HCN atau asam sianida merupakan zat yang bersifat racun baik dalam bentuk bebas maupun kimia, yaitu glikosida, sianogen phaseulonathin, linamarin dan metillinamarin/lotaustrain (Coursey, 1973).

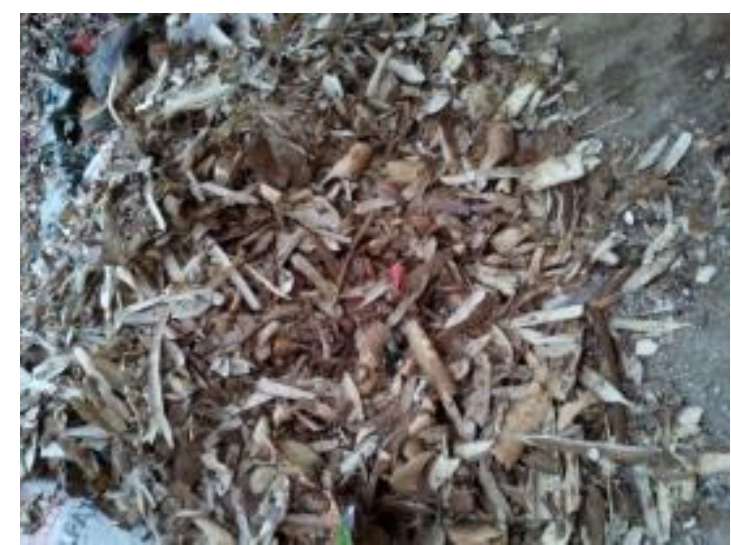

Gambar 1.2 Limbah Kulit Singkong

Penumpukan limbah seperti Gambar 1.2 adalah akibat kurangnya pengetahuan masyarakat, terutama pelaku usaha produksi tape singkong dalam pengelolaan dan pengolahan limbah kulit singkong. Masyarakat perlu diberikan sosialisasi dan inisiasi tentang bagaimana cara mengelola dan mengolah limbah yang jumlahnya melimpah sehingga mampu mengangkat nilai ekonomis dari limbah tersebut serta dapat bermanfaat bagi masyarakat sekitar. 


\subsection{Permasalahan Mitra}

\section{a. Identifikasi permasalahan yang dihadapi}

Berdasarkan analisa situasi dan kondisi lingkungan home industri tape singkong diatas, ada beberapa persoalan terkait dengan adanya penumpukan limbah tape singkong yang dapat diringkas pada Tabel 1.1 berikut.

Tabel 1.1 Persoalan di Home Industri Tape Singkong Maesan Bondowoso

\begin{tabular}{lll}
\hline No & \multicolumn{1}{c}{ TINJAUAN } & \multicolumn{1}{c}{ PERSOALAN } \\
\hline $\mathbf{l}$ & $\begin{array}{l}\text { Manajemen Pengelolaan } \\
\text { sampah dan limbah } \\
\text { industri }\end{array}$ & $\begin{array}{l}\text { Limbah home industri tape singkong dibuang begitu saja } \\
\text { begitu saja bercampur dengan sampah lainnya serta } \\
\text { ditumpuk di lahan terbuka tanpa ada pemilahan dan } \\
\text { mengganggu estetika lingkungan. }\end{array}$ \\
$\mathbf{2}$ & Pengolahan limbah & $\begin{array}{l}\text { Pelaku usaha home industri belum mengetahui cara } \\
\text { pengolahan limbah kulit singkong menjadi lebih } \\
\text { bermanfaat. }\end{array}$ \\
\hline
\end{tabular}

Dari analisa situasi diatas maka akan muncul persoalan terkait evaluasi pengelolaan sampah dan limbah home industri tape singkong serta masyarakat sekitar, diantaranya:

1. Pola pembuangan sampah dan limbah yang burukserta manajemen pengolahan sampah yang belum tertata.

2. Kurangnya pengetahuan pelaku usaha home industri tape singkong dan masyarakat sekitar akan pentingnya pengolahan limbah bagi lingkungan.

\section{b. Justifikasi Prioritas Penyelesaian Permasalahan yang Ditangani}

Sesuai urutan identifikasi masalah diatas, maka penyelesaian persoalan dimulai dengan:

1. Pemilahan sampah rumah tangga dan limbah kulit singkong pada tempat yang berbeda

2. Memberi sosialisasi tentang pengelolaan sampah, pengolahan limbah dan dampaknya pada lingkungan.

3. Menginisiasi dan memberikan bantuan kepada masyarakat contoh rekator biogas skala rumah tangga yang nantinya dapat diperbanyak sesuai kebutuhan serta memberikan pengetahuan tentang pembuatan biobriket dari limbah kulit singkong.

Dengan adanya tahap-tahap penyelesaian diatas diharapkan mampu membantu menyelesaikan masalahsampah dan limbah di daerah sentra industri tape singkong Maesan Bondowoso dan masyarakat sekitarnya.

\section{BAB 2. SOLUSI DAN TARGET LUARAN}

\subsection{Solusi yang Ditawarkan}

Masalah yang dihadapi pada area penelitian ini adalah menumpuknya sampah dan limbah kulit singkong akibat kurangnya pengetahuan masyarakat tentang pengelolaan sampah yang baik dan cara pengolahan limbah kulit singkong. Pertumbuhan sektor home industri tape singkong yang semakin meningkat berpotensi meningkatkan limbah yang dihasilkan saat proses produksi. Melimpahnya limbah yang tidak termanfaatkan sangat erat kaitannya dengan potensi pencemaran lingkungan sehingga perlu dicari solusi dalam penanganan limbah tersebut. 
Jumlah kulit singkong yang berada dalam jumlah besar ini dapat dimanfaatkan sebagai bahan baku energi terbarukan yang ramah lingkungan limbah kulit singkong yang awalnya berdampak negatif pada lingkungan dapat dijadikan produk baru dengan nilai ekonomis yang lebih tinggi. Berdasarkan literatur, limbah kulit singkong berpotensi untuk menjadi sumber energi terbarukan karena perannya sebagai limbah biomassa. Biogas dan biobriket adalah beberapa bahan bakar alternatif yang dapat diproduksi dari limbah kulit singkong.

\subsection{Target Luaran}

Indikator keberhasilan suatu kegiatan adalah adanya perubahan antara sebelum diadakan kegiatan pengabdian masyarakat dan sesudah adanya kegiatan pengabdian kepada masyarakat. Berkaitan dengan kegiatan Program Kemitraan Masyarakat di sentra home industri tape singkong "Seger Wareg" Jalan Bondowoso-Jember, RT 004/RW 001, Desa Gambangan, Kecamatan Maesan, Kabupaten Bondowoso. Uraian target yang ingin dicapai dalam kegiatan pengabdian masyarakat ditunjukkan pada Tabel 2.l. Tabel tersebut menjelaskan aspek manajemen pengelolaan sampah yang juga berkaitan langsung dengan kebersihan dan kesehatan lingkungan. Selain itu, masyarakat juga mempunyai wawasan cara pengelolaan sampah yang baik dan benar serta mampu menghasilkan nilai tambah bagi kehidupan masyarakat. Hal lain yang menjadi target adalah dapat terpublikasinya hasil dari kegiatan pengabdian ini dalam jurnal nasional.

Tabel 2.1 Target Capaian

\begin{tabular}{|c|c|c|c|}
\hline \multirow[t]{2}{*}{ No } & \multirow[t]{2}{*}{ Jenis Pengamatan } & \multicolumn{2}{|c|}{ Target Luaran } \\
\hline & & Sebelum Kegiatan & Sesudah Kegiatan \\
\hline 1 & $\begin{array}{l}\text { Manajemen pengelolaan } \\
\text { sampah }\end{array}$ & $\begin{array}{l}\text { Terdapat tumpukan sampah dan } \\
\text { limbah tape singkong di lahan } \\
\text { pembuangan yang sama }\end{array}$ & $\begin{array}{l}\text { Dilakukan pemilahan sampah } \\
\text { rumah tangga dan limbah kulit } \\
\text { singkong serta penataan lokasi } \\
\text { pembuangan yang tidak } \\
\text { mengganggu masyarakat dan } \\
\text { estetika lingkungan }\end{array}$ \\
\hline 2 & $\begin{array}{l}\text { Pengolahan limbah kulit } \\
\text { singkong }\end{array}$ & $\begin{array}{l}\text { Masyarakat belum mengetahui } \\
\text { secara detail tentang pengolahan } \\
\text { limbah kulit singkong agar bisa } \\
\text { menjadi produk dengan nilai } \\
\text { ekonomis lebih tinggi dan } \\
\text { bermanfaat bagi masyarakat. }\end{array}$ & $\begin{array}{l}\text { Masyarakat mengetahui } \\
\text { bagaimana cara membuat } \\
\text { rekator biogas, memproduksi } \\
\text { biogas dan biobriket sebagai } \\
\text { bahan bakar alternatif dari } \\
\text { pemanfaatan limbah kulit } \\
\text { singkong hasil produksi tape. }\end{array}$ \\
\hline 3 & Jurnal nasional & - & $\begin{array}{l}\text { Diterimanya l jurnal nasional } \\
\text { terakreditasi dengan judul } \\
\text { "Pemanfaatan } \\
\text { Produksi Tape Singkong } \\
\text { Sebagai Sumber Energi } \\
\text { Alternatif Biogas Dan } \\
\text { Biobriket Untuk Industri } \\
\text { Rumah Tangga". }\end{array}$ \\
\hline
\end{tabular}

Tabel 2.2 berikut ini menjelaskan target luaran yang hendak dicapai terkait pelaksaaan Pengabdian Dosen Pemula di sentra home industri tape singkong Maesan Bondowoso.

Tabel 2.2 Rencana Target Luaran

\begin{tabular}{lll}
\hline No & \multicolumn{1}{c}{ Jenis Luaran } & Indikator Capaian \\
\hline \multicolumn{2}{l}{ Luaran Wajib } & diterima \\
\hline & Publikasi ilmiah pada jurnal ber-ISSN atau prosiding jurnal nasional & ada \\
2 & Publikasi pada media masa cetak/online/repocitory PT & ada \\
\hline 3 & Peningkatan daya saing (peningkatan kualitas, serta nilai tambah & ada \\
\hline
\end{tabular}




\begin{tabular}{|c|c|c|}
\hline & barang, jasa, diversifikasi produk, atau sumber daya lainnya) & \\
\hline 4 & $\begin{array}{l}\text { Peningkatan penerapan iptek di masyarakat (mekanisasi, IT, dan } \\
\text { manajemen) }\end{array}$ & $\mathrm{ada}$ \\
\hline 5 & $\begin{array}{l}\text { Perbaikan tata nilai masyarakat (seni budaya, sosial, politik, } \\
\text { keamanan, kerentraman, pendidikan, kesehatan) }\end{array}$ & ada \\
\hline \multicolumn{3}{|c|}{ Luaran Tambahan } \\
\hline 1 & Publikasi di jurnal internasional & Tidak ada \\
\hline 2 & Jasa, rekayasa sosial, metode atau sistem, produk/barang & Belum \\
\hline 3 & Inovasi baru TTG & Belum \\
\hline 4 & $\begin{array}{l}\text { Hak kekayaan intelektual (Paten, Paten sederhana, Hak cipta, } \\
\text { Merek dagang, Rahasia dagang, Desain produk industri, } \\
\text { Perlindungan varietas tanaman, Perlindungan desain topografi } \\
\text { sirkuit terpadu }\end{array}$ & Tidak Ada \\
\hline 5 & Buku ber ISBN & Tidak Ada \\
\hline
\end{tabular}

\section{BAB 3. METODE PELAKSANAAN}

\section{1 Perencanaan Sosialisasidan Pembekalan Manajemen Pengelolaan Sampah serta Pengolahan Limbah}

Materi sosialisasi dan pembekalan serta tujuan dari pemberian materi dijelaskan pada Tabel 3.1 berikut.

Tabel 3.1 Materi Sosialisasi dan Pembekalan Kegiatan Pengabdian Masyarakat

\begin{tabular}{|c|c|c|c|}
\hline No. & Jenis Materi Pembekalan & Tujuan Pemberian Materi & Peserta Pembekalan \\
\hline 1 & $\begin{array}{l}\text { Manajemen } \\
\text { pengelolaansampah }\end{array}$ & $\begin{array}{l}\text { Untuk memastikan } \\
\text { masyarakat mampu } \\
\text { melakukan manajemen } \\
\text { pengelolaan sampah yang } \\
\text { sesuai standart dan } \\
\text { berkelanjutan }\end{array}$ & $\begin{array}{l}\text { Pelaku usaha home insutri } \\
\text { tape singkong "Seger } \\
\text { Waras" Maesan Bondowoso } \\
\text { dan masyarakat sekitar. }\end{array}$ \\
\hline 2 & $\begin{array}{l}\text { Pengolahan Limbah Kulit } \\
\text { Singkong Hasil Samping } \\
\text { Produksi Tape Singkong }\end{array}$ & $\begin{array}{l}\text { Untuk memberikan } \\
\text { contoh pembuatan } \\
\text { reaktor biogas skala } \\
\text { rumah tangga serta } \\
\text { memberikan pengetahuan } \\
\text { tentang proses produksi } \\
\text { biogas dan biobriket yang } \\
\text { dapat dimanfaatkan } \\
\text { sebagai bahan bakar } \\
\text { alternatif. }\end{array}$ & $\begin{array}{l}\text { Pelaku usaha home insutri } \\
\text { tape singkong "Seger } \\
\text { Waras" } \\
\begin{array}{l}\text { Bondowoso } \\
\text { masyarakat sekitar. }\end{array}\end{array}$ \\
\hline
\end{tabular}

Dengan dilakukannya sosialisasi dan pembekalan terhadap pelaku usaha sentra home industri tape singkong dan masyarakat sekitar diharapkan kegiatan pengabdian masyarakat dapat terlaksana dan berjalan dengan baik.

\subsection{Pelaksanaan Pemilahan Sampah dan Relokasi Sampah Rumah Tangga dan Limbah Kulit Singkong}

Setelah dilakukan evaluasi, langkah selanjutnya adalah pengelolaan sampah dan limbah serta pembuatan reaktor bioagas skala rumah tangga. Pelaksanaan pengelolaan sampah dilakukan oleh pelaku home industri tape singkong beserta warga sekitar dipimpin oleh perangkat desa dengan dipandu oleh tim pengabdian masyarakat dari Universitas Jember. Dengan keterlibatan warga dalam kegiatan tersebut diharapkan mampu mengembangkan wilayahnya untuk pengembangan kearah yang lebih baik. 


\subsection{Pelaksanaan Produksi Biogas dan Biobriket dari Limbah Kulit Singkong Hasil \\ Samping Produksi Tape Singkong}

Produksi biogas dalam penelitian ini menggunakan reaktor biogas skala rumah tangga dengan memanfaatkan galon air volume 6 liter dengan menggunakan kotoran sapi sebagai starter. Berikut adalah detail reaktor yang akan dilakukan pada penelitian ini.

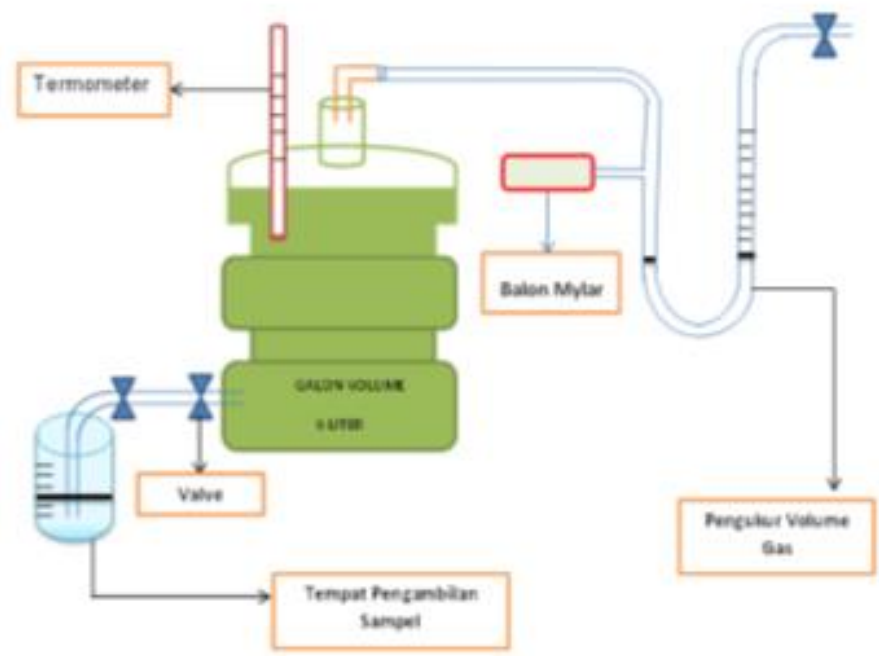

Gambar 3.1 Detail Reaktor Biogas

Briket kulit singkong yang akan dibuat terdiri dari jenis briket kayu dan briket arang. Briket kayu merupakan briket yang bahan bakunya tanpa melalu proses karbonasi (pengarangan) terlebih dahulu. Sedangkan briket arang merupakan briket yang bahan bakunya melalui proses karbonasi. Perbedaan briket kayu dan briket arang dapat dilihat pada skema diagram alir proses pembuatan briket pada Gambar 3.2 .

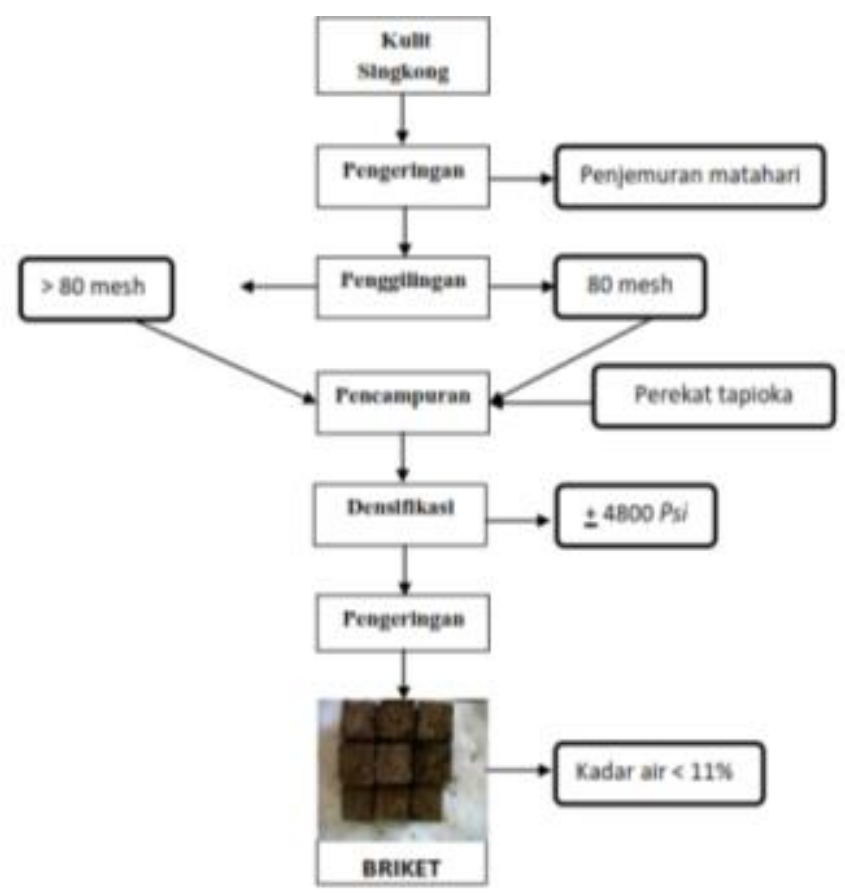

Gambar 3.2 Pembuatan Biobriket 


\section{HASIL DAN PEMBAHASAN}

Kegiatan pengabdian kepada masyarakat berupa pemanfaatan limbah produksi tape singkong sebagai sumber energi alternatif biogas dan biobriket untuk industri rumah tangga telah dilaksanakan dengan baik. Detail hasil dan pembahasan kegiatan pengabdian kepada masyarakat diuraikan dalam Bab ini.

\subsection{Pembuatan Reaktor}

Berbagai jenis reaktor biogas telah banyak dikembangkan mulai dari skala kecil hingga skala besar. Pemilihan jenis reaktor yang dipakai dengan mempertimbangkan kemudahan dalam instalasi, pertimbangan lokasi, skala penggunaan serta pertimbangan biaya investasi yang akan dikeluarkan. Kegiatan pengabdian masyarakat ini menggunakan reaktor biogas skala kecil dari bahan galon untuk penggunaan rumah tangga yang praktis karena dapat dipindahkan dengan mudah dan dapat diparalelkan antara galon yang satu dengan yang lainnya. Hasil produk reaktor yang dibuat dapat dilihat pada Gambar 4.1.

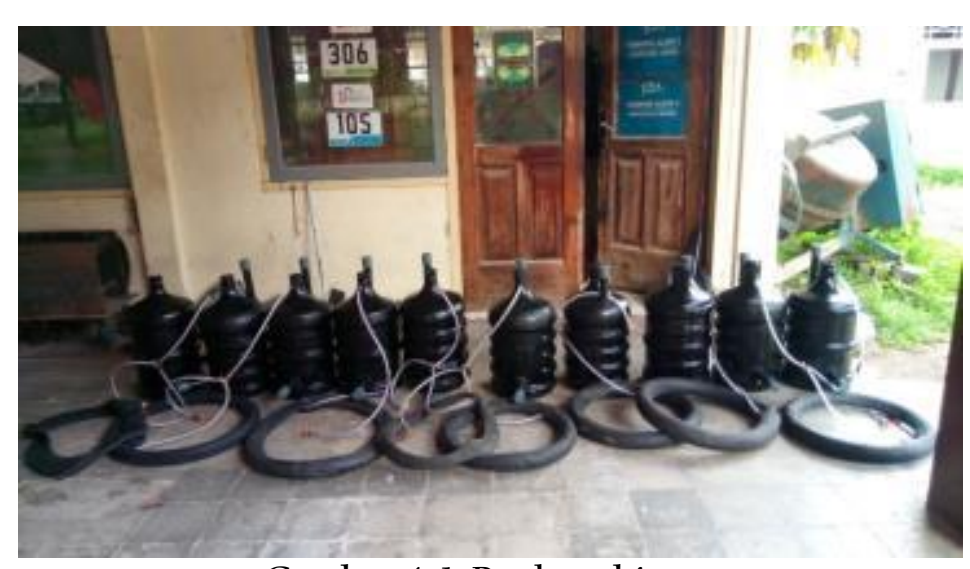

Gambar 4. 1: Reaktor biogas

Pembuatan reaktor biogas melibatkan melibatkan mahasiswa dari Jurusan Teknik Sipil dan Jurusan Teknik Mesin Fakultas Teknik Universitas Jember. Tahap awal pembuatan adalah dengan menyiapkan alat-alat yang akan digunakan lalu memotong pipa dan selang dengan ukuran tertentu. Kemudian selanjutnya melubangi bagian gallon untuk inlet dan outlet. Semua bahan lalu dirangkai dan dilakukan pengeleman agar tidak ada kebocoran hingga membentuk sebuah reactor dari gallon. Penampungan gas menggunakan ban dalam. Proses pembuatan reaktor biogas dapat dilihat pada Gambar 4.2. 


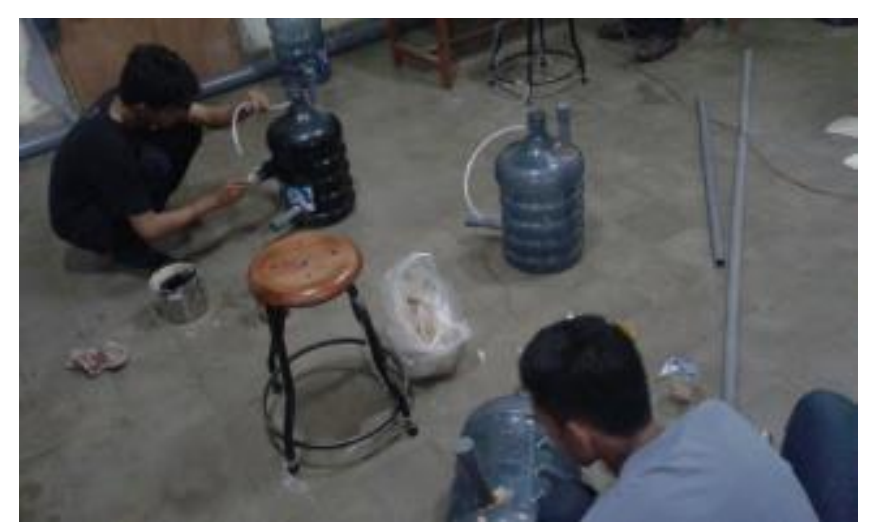

Gambar 4. 2: Proses pembuatan biogas

\subsection{Pembuatan Briket}

Pembuatan briket dilakukan dengan menggunakan bahan dasar limbah kulit singkong. Pada tahap awal kulit singkong dibersihkan terlebih dahulu menggunakan air untuk memisahkan kotoran. Lalu kulit singkong dihaluskan dengan cara digiling hingga menyerupai tepung. Kemudian kulit singkong yang telah dihaluskan tersebut dicetak menggunakan alat pres. Agar tepung kulit singkong dapat menyatu dengan baik, digunakan tepung topioka sebagai perekat. Pada tahap akhir sebelum digunakan, briket terlebih dahulu dikeringkan dengan cara dijemur atau di oven. Gambar 4.3 menunjukan cara pembuatan briket dari bahan kulit singkong.
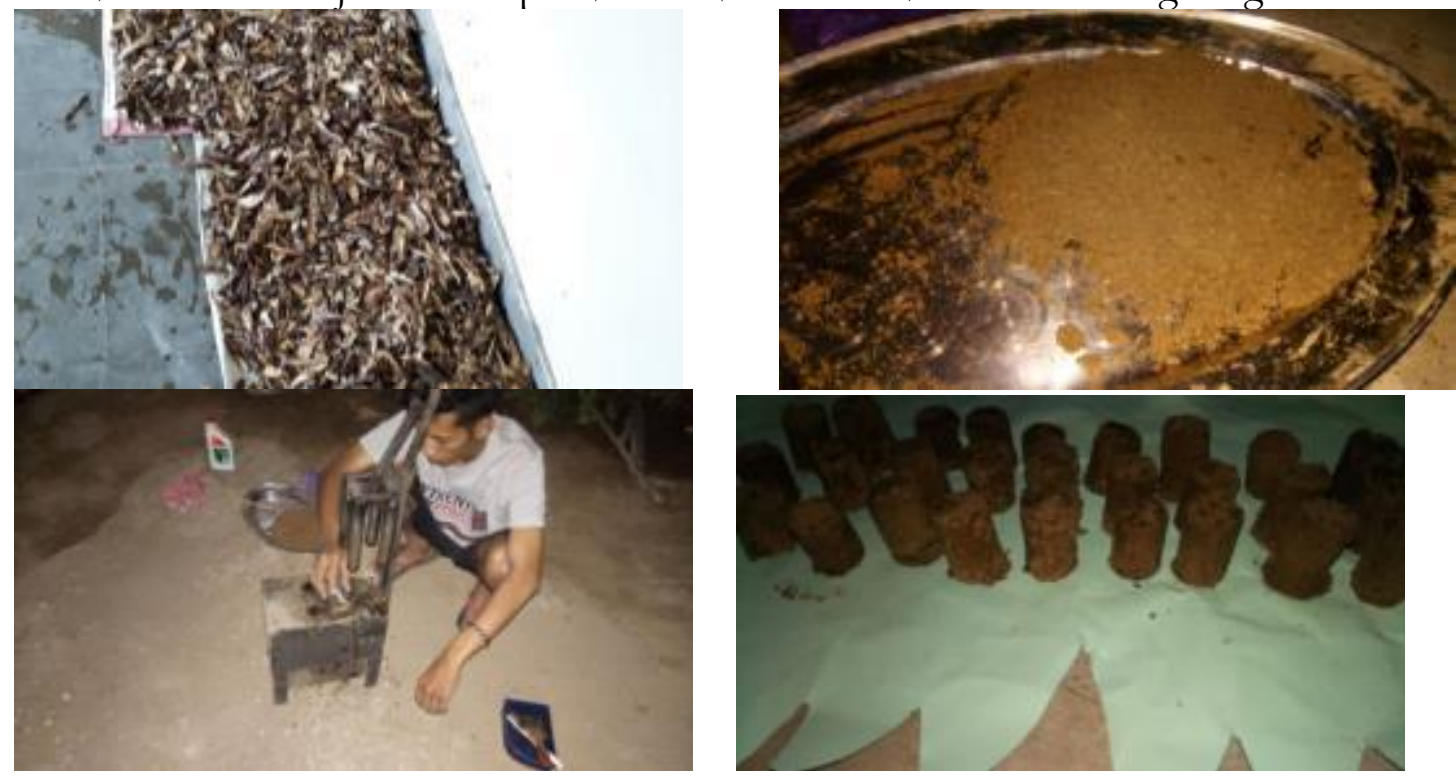

Gambar 4. 3 : Pembuatan briket

\subsection{Pengoperasian Reaktor}

Pengoperasian reaktor untuk mendapatkan biogas sangatlah mudah dan dapat dilakukan oleh masyarakat luas. Adapun langkah-langkah pengoperasian biogas adalah sebagai berikut.

1. Pembuatan campuran kotoran sapi, air dan limbah kulit singkong dengan perbandingan 1:2:1. Kotoran sapi digunakan sebagai starter dengan kandungan bakteri anaerobik tinggi.

2. Campuran dimasukkan kedalam reaktor hingga mencapai $1 / 3$ dari kapasitas reaktor, kemudian dibiarkan di tempat yang gelap agar proses fermentasi anaerobik dapat berlangsung dengan baik. 
3. Setelah 14 hari, ban dalam yang digunakan sebagai tempat penampungan gas terlihat telah mengembang, kemudian kran dibuka sedikit untuk mengeluarkan udara yang terjebak didalam penampungan gas. Setelah itu dapat dilakukan uji nyala api pada biogas.

4. Selanjutnya jika biogas dalam penampungan telah habis maka dapat dilakukan pengisian kembali dengan bahan pembentuk biogas. Bahan dapat divariasikan menggunakan sampah limbah sayuran, buah, air cucian beras dan sebagainya sesuai dengan bahan yang tersedia.

Biogas yang dihasilkan dapat digunakan untuk memasak dengan cara selang disambungkan ke kompor biogas dan menggunakan pemantik api agar kompor dapat menyala. Besar kecilnya nyala api dapat diatur dengan mengatur bukaan keran pipa atau selang. Proses pengoperasian biogas dapat dilihat pada Gambar 4.4.
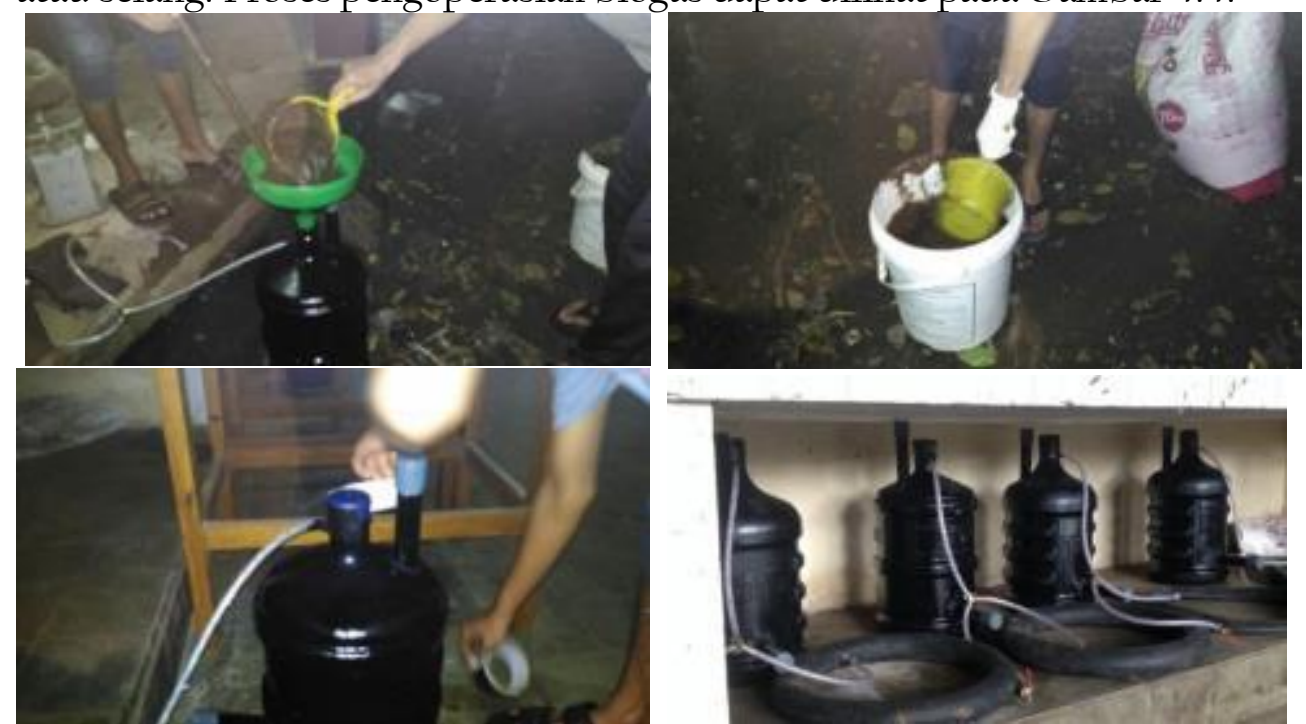

Gambar 4. 4: Pengoperasian biogas

\subsection{Pelatihan dan Sosialisasi Pengelolaan Sampah}

Pelatihan dan sosialisasi pembuatan biogas dilaksanakan di area pekarangan industri rumahan tape Maesan. Kegiatan meliputi; (a) pemaparan materi oleh tim pelaksana pengabdian masyarakat, (b) diskusi, (c) praktek pembuatan reaktor dan (d) uji nyala api.

Pemaparan materi diikuti oleh 20 orang peserta dari warga disekitar lokasi produksi industri rumahan tape Maesan. Materi yang disampaikan meliputi; (a) pengenalan biogas, (b) cara pembuatan reaktor, (c) pengoperasian biogas dan perawatan dan (d) manfaat biogas untuk kelangsungan hidup manusia. Suasana penyampaian materi dapat dilihat pada Gambar 4.5.

Pemaparan sosialisasi juga meliputi cara pengelolaan sampah rumah tangga yang meliputi pembatasan timbulan sampah, pendauran ulang sampah, dan pemanfaatan kembali sampah. Sedangkan kegiatan penanganan meliputi pemilihan, pengumpulan, pengangkutan, pengolahan dan pemrosesan akhir sampah. 

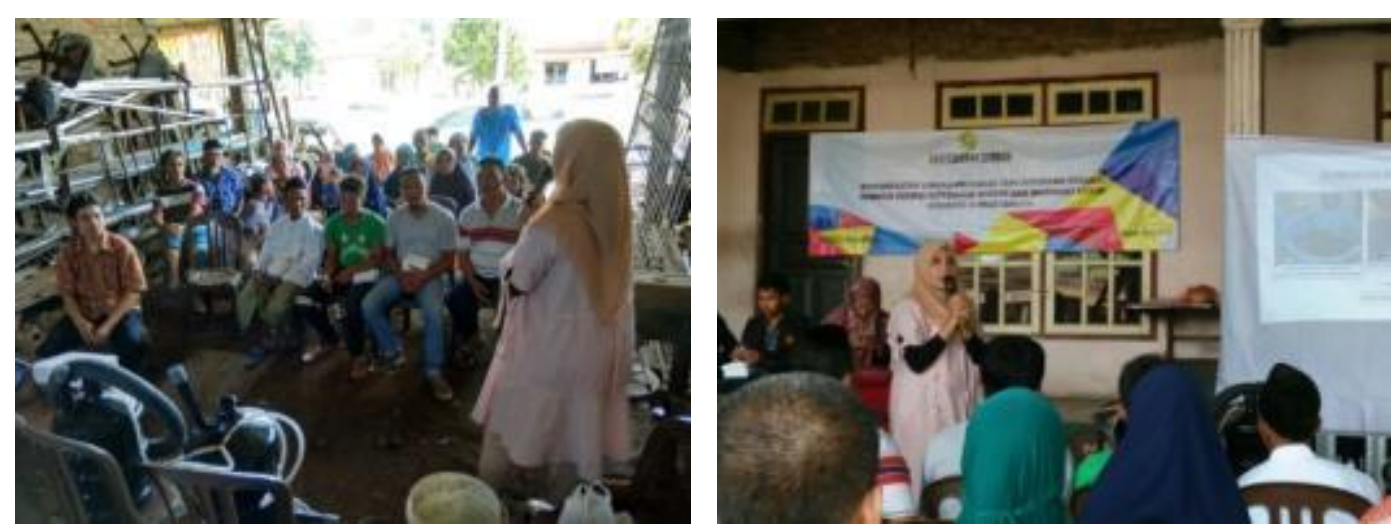

Gambar 4. 5: Penyampaian Materi

Setelah materi kemudian dilanjutkan dengan sesi diskusi berupa pertanyaan dari para peserta terkait dengan banyak hal yang berhubungan dengan pembuatan, pengoperasian dan manfaat biogas. Jalannya diskusi dapat dilihat pada Gambar 4.6.

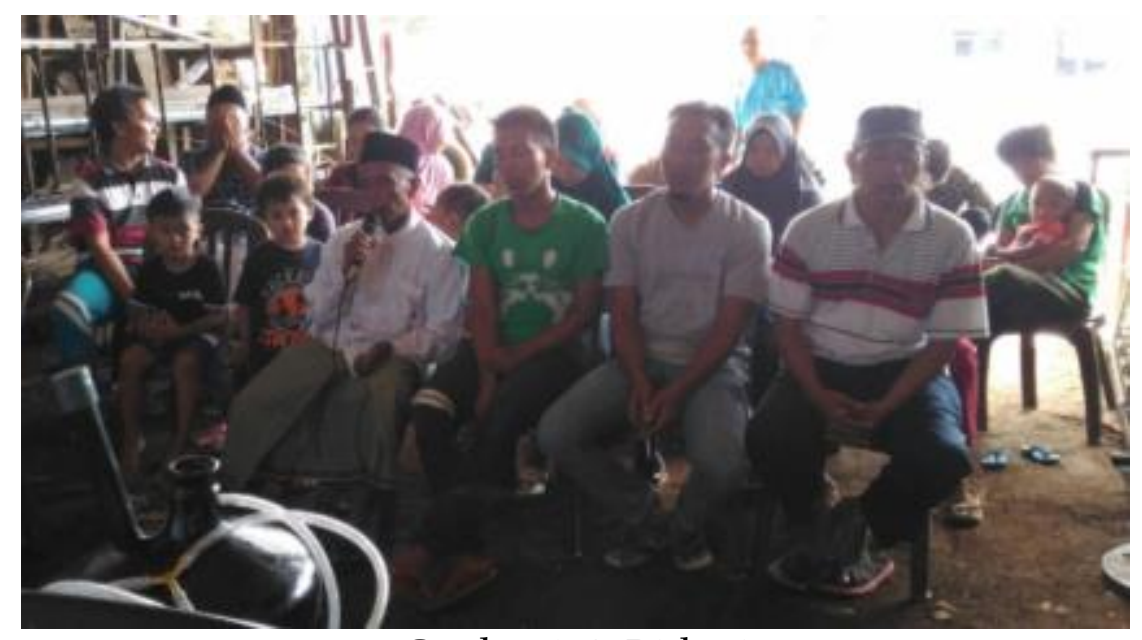

Gambar 4. 6 : Diskusi

Praktek pembuatan reaktor diperagakan oleh mahasiswa dan diikuti dengan antusias oleh para peserta yang hadir. Bahan-bahan terlebih dahulu telah disiapkan oleh pelaksana. Praktek pembuatan reaktor meliputi penjelasan ukuran-ukuran alat, penjelasan bahan dan alat yang digunakan dan proses pembuatan sampai reaktor jadi. Praktek pembuatan reaktor dapat dilihat pada Gambar 4.7.
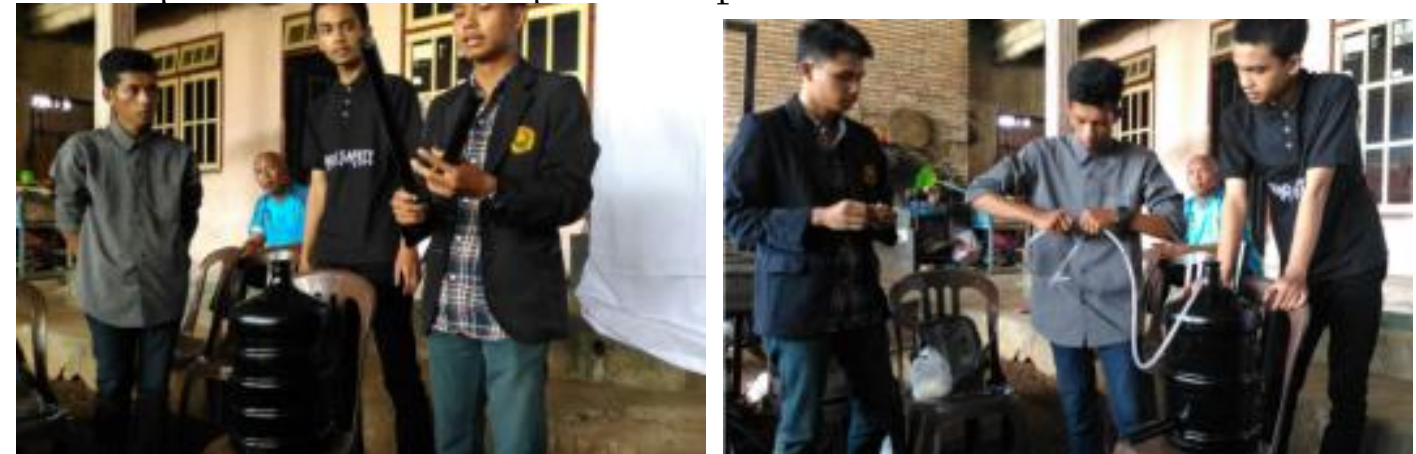

Gambar 4. 7: Praktek pembuatan reaktor 
Tahap akhir dari proses sosialisasi adalah percobaan uji nyala api. Dalam uji nyala api tersebut melibatkan peserta dan setelah diberi pemantik berupa api, terlihat nyala api berwarna biru dari keran selang dimana biogas mengalir keluar. Proses uji nyala api dapat dilihat pada Gambar 4.8.

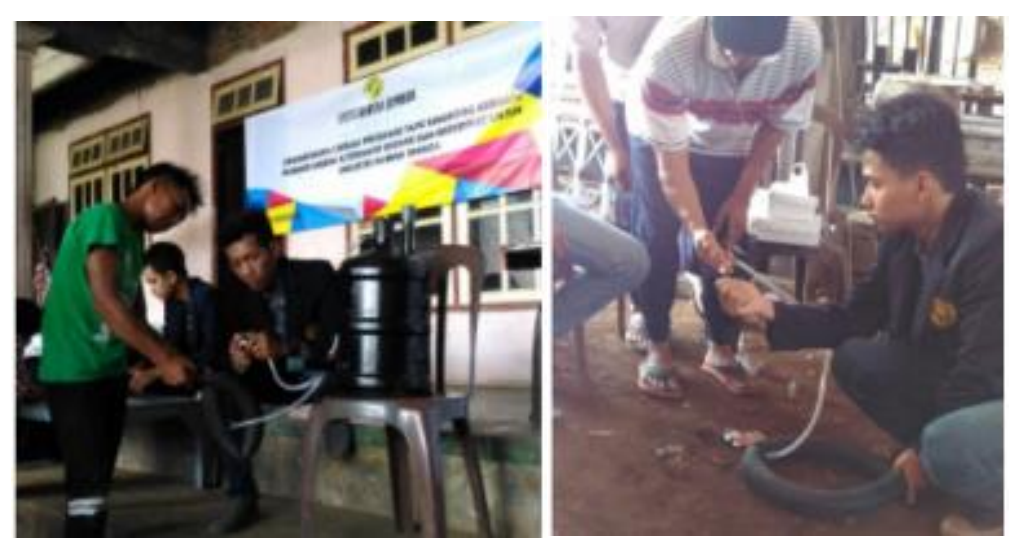

Gambar 4. 8: Uji nyala api

Pada sesi terakhir sebelum acara ditutup, dilakukan pembagian reaktor dan briket kepada warga serta foto bersama panitia dan peserta kegiatan pengabdian kepada masyarakat. Penyerahan reaktor dan briket dapat dilihat pada Gambar 4.9.
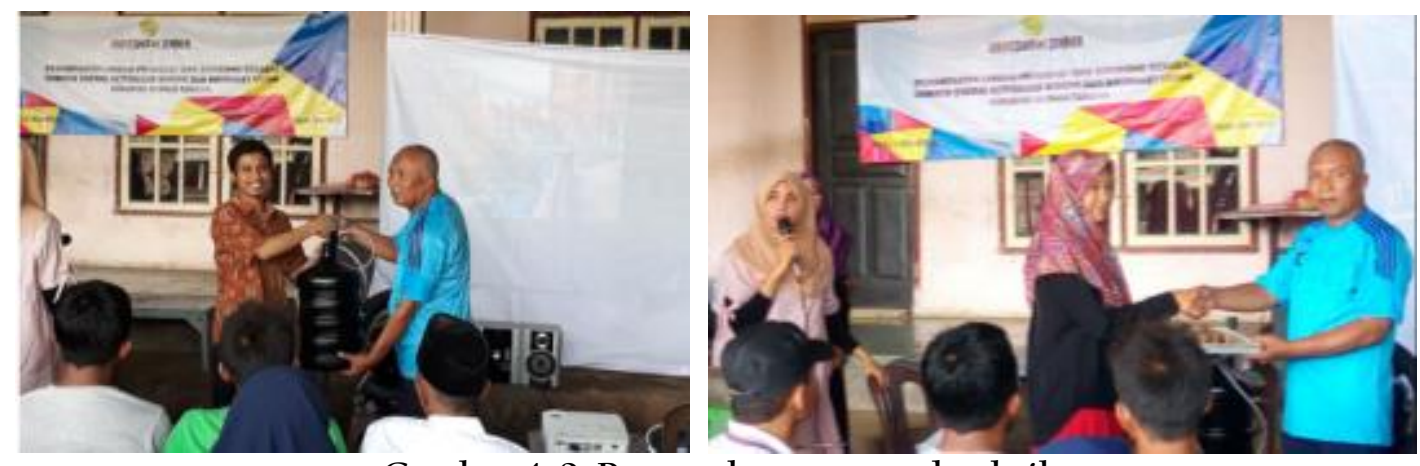

Gambar 4. 9: Penyerahan reactor dan briket

\section{KESIMPULAN DAN SARAN}

Kesimpulan yang dapat diambil dari dari kegiatan pengabdian masyarakat ini antara lain.

1. Target luaran yang diharapkan adalah meningkatkan pengetahuan dan pemahaman masyarakat terhadap biogas dan bio briket untuk kebutuhan skala rumah tangga.

2. Metode pelaksanaan berupa pemanfaatan limbah kulit singkong pada industry tape rumahan Maesan.

3. Hasil kegiatan pengabdian kepada masyarakat ini antara lain; (a) pemaparan materi oleh tim pelaksana pengabdian masyarakat, (b) reaktor biogas dan briket, (c) praktek pembuatan reaktor dan (d) uji nyala api terhadap biogas yang telah terbentuk.

Saran dalam kegiatan ini adalah sebagai berikut.

1. Proses pencairan dana dapat dilakukan lebih cepat, mengingat proses produksi biogas yang mebutuhkan waktu lama.

2. Perlu adanya pembinaan berkelanjutan terhadap mitra.

3. Biogas dapat dibuat dalam skala lebih besar dengan melibatkan stokeholder. 